\title{
Způsoby nakládání s bioodpadem v Praze a ve vybraných hlavních městech států Evropské unie
}

DAGMAR VOLOŠINOVÁ, ROBERT KOŘÍNEK, ELŽBIETA ČEJKA

Klíčová slova: bioodpad - nakládání s odpadem - oběhové hospodářství - kompostování - anaerobní digesce - Evropská unie

\section{SOUHRN}

Bioodpad neboli odpad podléhající anaerobnímu nebo aerobnímu rozkladu se díky způsobu využívání zelených ploch zejména ve velkých městech s velkou hustotou osídlení stal problematickou složkou komunálního odpadu. Na bioodpad Ize pohlížet jako na zdroj nebezpečného methanu uvolňovaného př́ skládkování, ale díky principům oběhového hospodářství se navracíme k jeho podstatě - zdroji živin a organické hmoty pro zemědělskou pưdu a městskou zeleň. Úspěšnost sběru bioodpadu, zpracování a návratu do životního prostředí se mezi jednotlivými hlavními městy členských států Evropské unie liší. Článek popisuje, jak efektivně se s danou problematikou vypořádává Praha ve srovnání s ostatními vybranými hlavními městy států Evropské unie.

\section{ÚVOD}

Bioodpad řadíme mezi biologicky rozložitelný odpad (BRO), který definuje směrnice Evropského parlamentu a Rady 1999/31/ES o skládkách odpadů jako odpad podléhající anaerobnímu nebo aerobnímu rozkladu, jako jsou potravinářské a zahradní odpady a rovněž papír a lepenka. Historicky byl BRO považován spíše za materiál, který byl spotřebován v místě svého vzniku. Postupem času, kdy hospodářské využití zelených ploch a zahrad jako zdroj píce pro chovaná hospodářská zvirrata a pěstování ovoce a zeleniny ustoupilo obytnému a volnočasovému využití, se na BRO začalo nahlížet jako na nepotřebný odpad, jehož způsob nakládání bylo potřeba upravit právními předpisy.

Evropská unie (EU) v současnosti upravuje nakládání s BRO dvěma hlavními předpisy: směrnicí Rady 1999/31/ES o skládkách odpadu a Rámcovou směrnicí Evropského parlamentu a Rady č. 98/2008/ES o odpadech. Problematiku BRO živočišného původu upravují nařízení Evropského parlamentu a Rady č. 1069/2009 Sb., o hygienických pravidlech pro vedlejší produkty živočišného původu a získané produkty, které nejsou určeny k lidské spotřebě (nařízení o vedlejších produktech živočišného původu) a nařízení Evropského parlamentu a Rady č. 853/2004 Sb., kterým se stanoví zvláštní hygienická pravidla pro potraviny živočišného pưvodu.

Směrnice Rady 1999/31/ES o skládkách odpadů ze dne 26. dubna 1999 má za cíl předcházet nebo maximálně omezit negativní dopady skládek na povrchové vody, podzemní vody, půdu, ovzduší a lidské zdraví. Směrnice také požaduje omezení skládkování biologicky rozložitelných komunálních odpadů v letech 2006, 2009 a 2016 na úroveň 75 \%, 50 \% a 35 \% produkce roku 1995. Státy jako Česká republika, Slovensko a Polsko, které v roce 1995 ukládaly na skládky více než 80 \% tuhých komunálních odpadů, požádaly o výjimku a povinnost splnění daných cílů jim byla posunuta o 4 roky.
Produkce komunálního odpadu (obr. 1) je ovlivněna životní úrovní obyvatelstva, zavedeným systémem odpadového hospodářství země a v neposlední radě osvětou a ekologickým smýšlením obyvatel. Je nutné si také uvědomit, že v zemích EU bioodpad tvoří největší složku komunálního odpadu (KO). Ve směsném komunálním odpadu (SKO) se vyskytuje i více než z 50 \% a z toho 30 \% představují zbytky potravin, slupky od ovoce a zeleniny, z 12 \% biologický odpad ze zahrad a $10 \%$ je tvořeno papírem a kartonem [1].

Mezi BRO spadají i odpady ze zemědělského, lesnického a potravinářského průmyslu, ale v tomto článku se budeme zabývat pouze biologicky rozložitelnými odpady spadajícími pod komunální odpad často zkráceně nazývanými komunální bioodpad. Směrnice Evropského parlamentu a Rady č. 98/2008/ES o odpadech uvádí, že bioodpad je tvořen biologicky rozložitelným odpadem ze zahrad a parků, potravinářskými a kuchyňskými odpady z domácností, restaurací, stravovacích a maloobchodních zařizení a srovnatelným odpadem ze zařízení potravinářského průmyslu.

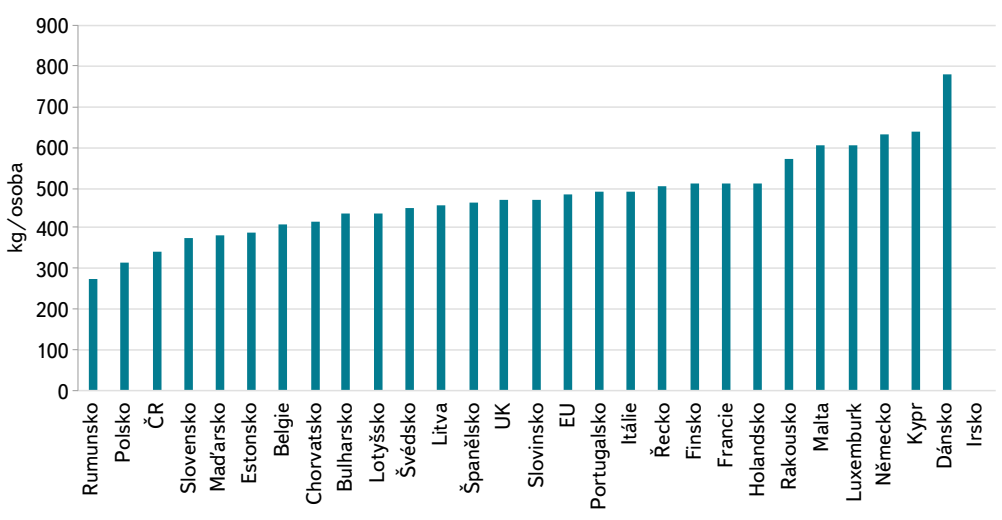

Obr. 1. Produkce komunálního odpadu na jednotlivce ve státech EU v roce 2017 [2] (pozn.: Irsko nedostupná data)

Fig. 1. Generation of municipal solid waste per capita in EU countries in 2017 [2] (note: Ireland unavailable data)

Přestože celkové procento skládkovaného odpadu v zemích EU klesá (obr. 2), mezi jednotlivými státy EU jsou velké rozdíly ve způsobech nakládání s KO, které souvisí se zavedeným odpadovým hospodářstvím. Rakousko, Nizozemsko, Dánsko, Německo, Švédsko a Belgie patří mezi lídry cirkulární ekonomiky. Mají komplexní systémy sběru odpadu, na skládky ukládají méně než 5 \% svého odpadu, mají dobře vyvinuté recyklační systémy, dostatečnou kapacitu technologií pro zpracování vytříděných složek KO a dobře nakládají i s biologicky rozložitelným odpadem. 


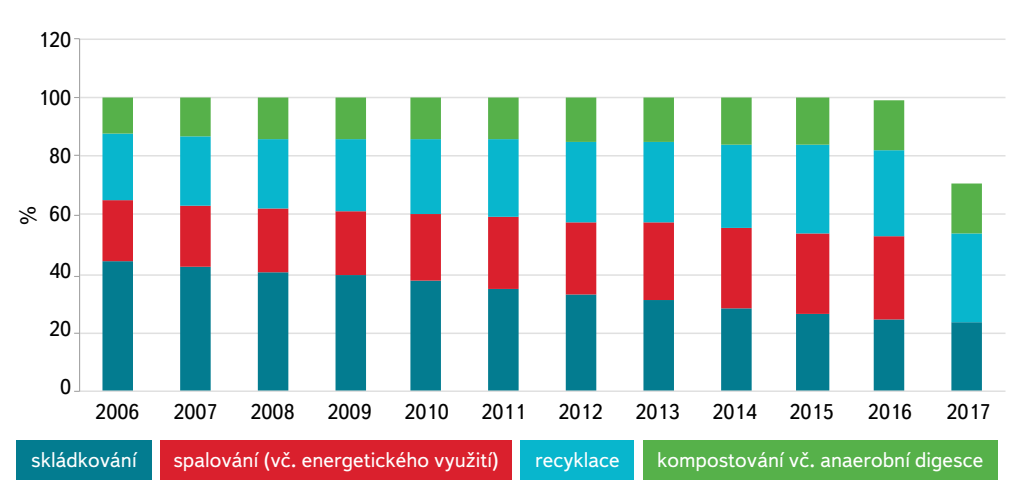

Obr. 2. Vývoj způsobů nakládání s komunálním odpadem v zemích EU [2] (pozn.: rok 2017 spalování - nedostupná data)

Fig. 2. Development of municipal waste management in EU countries [2] (note: year 2017 incineration - unavailable data)

Na opačném konci pomyslného žebřičcu se nacházejí státy jižní a východní Evropy, mezi které patři Řecko následované Bulharskem, Maltou, Litvou, Rumunskem a Kyprem. Hlavními nedostatky jsou špatné nebo neexistující systémy předcházení vzniku odpadů, nedostatek pobídek k přesměrování odpadu ze skládek a nedostatečná infrastruktura nakládání s odpady. Velké množství členských států svůj SKO převážně skládkuje, navzdory lepším alternativám a dostupnosti evropských strukturálních fondů pro pořizení technologií splňujících hierarchii nakládání s odpady a principy oběhového hospodářství. Některé státy jako problém pro zavedení ekologičtějších alternativ označily ekonomickou nekonkurenceschopnost nových technologií vưči skládkování [3].

\section{ZPU゚SOBY SBĚRU A NAKLÁDÁNÍ S BIOODPADEM}

Sběr bioodpadu Ize provádět dvěma postupy. První, finančně i časově náročnější pro zavedení, je oddělený sběr. Nicméně jde o sběr s čistším výsledným materiálem a se sniženým rizikem kontaminace nebezpečnými látkami. Oddělený sběr Ize provádět bud' pomocí sběrných nádob, nebo pytlů na úrovni domácností, restaurací, jídelen apod., svozovým systémem "door to door" (tzn. od domu k domu), dále pomocí kontejnerů ve sběrných hnízdech tříděného odpadu, velkoobjemovými kontejnery pravidelně přistavovanými do ulic anebo donáškou do sběrných dvorů.

Vytříděný bioodpad, jehož úroveň čistoty souvisí s mírou osvěty a spolupráce jednotlivých obyvatel, Ize kompostovat anebo zpracovat anaerobní digescí (AD) v bioplynových stanicích. Kompostování podle rozsahu rozdělujeme na domácí, vermikompostování, komunitní kompostování, na kompostování $v$ malých zařízeních (do 10 tun na jednu zakládku) a v centrálních kompostárnách. Anaerobní digesce probíhá centrálně v uzavřených technologiích, které podle vlhkosti vstupního materiálu rozdělujeme na mokrou (max. 12 \% sušiny) a suchou (min. $20 \%$ sušiny).

Při druhém postupu je bioodpad součástí SKO a k jeho zpracování lze použít technologii mechanicko-biologické úpravy, jejímž cílem je zmenšit objem SKO a stabilizovat ho tak, aby po uložení na skládku nedocházelo k výluhu nebezpečných látek, nevznikal methan, případně požáry. Pro zabránění takovýchto rizik Ize SKO s příměsí BRO energeticky využít v závodech energetického využití odpadů (ZEVO) nebo spálit. Tímto způsobem však znehodnotíme materiálovou složku BRO. V České republice vyhláška č. 294/2005 Sb., o podmínkách ukládání odpadů na skládky a jejich využivání na povrchu terénu limituje podíl biologické složky SKO pro rok 2020 na $35 \%$.

\section{BIOODPAD V HLAVNÍCH MĚSTECH ČLENSKÝCH STÁTŮ EU}

Ve velkých městech, kde je vysoká hustota obyvatel, restaurací, jídelen, hotelů a podobných zdrojů bioodpadů, je nakládání s bioodpadem složitější, ale Ize ríci, že míra úspěšnosti plnění principů oběhového hospodářství hlavních měst je shodná s úspěšností států.

Hlavní města států EU podle zavedených systémů nakládání s bioodpadem Ize rozdělit do tří skupin. Do první patří ty, které dodržují hierarchii nakládání s odpady a principy oběhového hospodářství ještě před zavedením recyklačních a skládkových limitů výše uvedenými směrnicemi. Bioodpad zpracovávají kompostováním, anaerobní digescí nebo kombinací obou. Digestát se po ukončení procesu vyhnívání většinou stává součástí kompostové zakládky a fugát je využit jako tekuté hnojivo pro zemědělské pozemky. Kompost je prodáván zemědělcům nebo je využíván v městské zeleni, eventuálně je zdarma rozdáván obyvatelům města. Neustálou osvětou jsou obyvatelé motivováni k preventivním opatřením zabraňujícím vznik odpadu a ke kompostování na vlastních pozemcích či v rámci komunit. Svozem separovaného bioodpadu jedenkrát týdně "door to door" je obslouženo 100 \% obyvatelstva. Řadíme sem Brusel, který vyvijí velké úsilí pro osvětu a motivaci rezidentů k vlastnímu kompostování. Berlín preferuje anaerobní digesci, z důvodu uzavřené bezzápachové technologie. Vzniklý bioplyn je využíván pro pohon svozových aut a za rok ušetří až 2,5 milionů litrů nafty. Amsterodam splňuje limity spálením veškerého zbytkového KO bez separace bioodpadu, která je zavedena pouze $v$ jedné městské čtvrti. Kodaň v současnosti skládkuje méně než $2 \%$ vyprodukovaného odpadu, prestože většinu energeticky využije. Odpad, který lze spálit je zakázáno skládkovat. Cena za skládkování je desetkrát větší než za spalování. Od roku 2017 má Kodaň nejvýkonnější spalovnu v Evropě a soustřed'uje se také na maximální recyklaci. Jako prístavní město zavádí program pro separaci bioodpadu z lodí, vede osvětové kampaně pro prevenci vzniku bioodpadů zejména "gastro“. Lucemburk na rozdíl od ostatních, kteří využívají systémy třídění "door to door" doplněné o možnost využití sběrných dvorů, preferuje donášku do kontejnerových hnízd. Vídeň třídí bioodpad od rezidentů i od právnických osob od roku 1991 a má 100\% obslužnost. Přestože provozuje ZEVO, snaží se o maximální materiálové využití bioodpadu a o návrat cenných živin zpět do půdy [4-11].

Do druhé skupiny řadíme města, která zavedla třídění až na základě požadavků právních předpisů EU. Např́klad Londýn plní limity pomocí energetického využivání, které, na rozdíl od první skupiny hlavních měst, v poslední době stoupá. Sběr tříděného odpadu řeší pomocí pytlového nebo nádobového sběru "door to door", nicméně není plošně zaveden pro celé město. Stejně tak i v Lisabonu je již od roku 2005 bioodpad separován pouze od třetiny obyvatel, není možnost odevzdat bioodpad ve sběrném dvoře a přednostně jsou za úplatu obslouženi podnikatelé. Řím má odpadové hospodářství dobře nastavené, ale velký vliv na jeho fungování mají politické změny jak ve státě, tak $\checkmark$ městském zastupitelstvu. Pro splnění limitů odklonu odpadů od skládkování využívá kapacit rakouských ZEVO, kam v roce 2017 vlaky z Říma týdně vozily až 700 tun SKO. Helsinky se řadí mezi nejlepší "třídiče" odpadů, a to díky masivnímu informačnímu systému (informace jsou podávány ve finštině, angličtině, ruštině, kurdštině, somálštině a arabštině), 75 \% obslužnosti obyvatel je realizováno systémem "door to door" a také díky poplatkům motivujícím k třídění. Separovaný bioodpad rozdrtí a rozdělí na dvě frakce. Jemná frakce (6-8 mm), která představuje $70 \%$ nashromážděného bioodpadu je zplyněna a hrubší frakce je kompostována. Paříž nemá plošný sběr vytříděného bioodpadu, nicméně disponuje 187 veřejně dostupnými kompostovacími místy. $V$ současnosti Paříž zavádí několik projektů pro separaci jak "gastro" (tzn. biologicky rozložitelný odpad z kuchyní a stravoven), tak zahradního bioodpadu, který by měl být upraven pomocí anaerobní digesce a navrácen v podobě hnojiva do půd. Sběr "door to door" by měl probíhat i pomocí biorozložitelných sáčků firmy Novamon. Nadále má být podporováno individuální kompostování rezidenty. 
Stockholm přes 50 \% vyprodukovaného odpadu energeticky využívá. Skládkuje pouze $1 \%$ odpadu. Bioodpad separuje systémem "door to door" pouze od $12 \%$ rezidentů. Nově stavěné bytové domy jsou opatřeny drtiči kuchyňského odpadu, který je shromažd’ován u paty domu, odkud je odvážen do bioplynové stanice. Kromě získání organické hmoty vidí Stockholm prínos ve snížení počtu svozů SKO [12-28].

Ve třetí skupině jsou města Talin, Budapešt', Bukurešt, Sofie, Athény, Dublin, Valletta, Záhřeb, Varšava, Vilnius, Bratislava, která, stejně jako celé jejich státy, mají se splněním limitů stanovených prededpisy EU velké problémy. Jako př́iklad za všechny Ize uvést Madrid, který celkově recykluje pouze 19,6 \% KO a odděleně sbírá pouze plast, kov a nápojový karton systémem „door to door". Separaci bioodpadu a konečné zpracování kompostováním a anaerobní digescí plánuje zavést od roku 2019 [29-39].

\section{BIOODPAD V PRAZE}

Kraj hl. m. Praha za rok 2017 celkem vyprodukoval 430300 tun komunálního odpadu, z toho přibližně $83 \%$ využil, a to $27 \%$ materiálově a $56 \%$ energeticky. $\checkmark$ roce 2017 bylo na skládku uloženo 12,7 \% komunálního odpadu [40].

Zájemci o svoz bioodpadu si mohou od Pražských služeb pronajmout kompostejnery, které jsou za úplatu sváženy $v$ sezoně (od 1. 4. do 30. 11.) jednou za dva týdny [41]. Svoz bioodpadu používá již přes 13 tisíc pražských domácností [42]. Zahradnictví a domácnosti, kde je bioodpad produkován po celý rok, si mohou nasmlouvat celoroční svoz s frekvencí $1 x$ za 14 dní. Mnoha osvětovými akcemi je podporováno domácí kompostování. Praha v rámci projektu „Podpora domácího kompostování na území hl. m. Prahy“ poskytuje zdarma zájemcům - fyzickým osobám - zapůjčení kompostérů. Ve všech pražských částech jsou do ulic v pravidelných intervalech přistavovány velkoobjemové kontejnery na posečenou trávu, listí, ořezané větve. Po celý rok mohou rezidenti zdarma odvážet svůj bioodpad do 27 sběrných dvorů. V sídlištích Prahy 13 a 15 byl zaveden pilotní projekt svozu tříděného bioodpadu. Bioodpad je kontrolován a zpracováván v kompostárnách a převážně "gastro" odpad je odvážen do bioplynové stanice Přibyšice.

V rámci prací na projektu CZ.07.1.02/0.0/0.0/16_040/0000379 Odpady a předcházení jejich vzniku - praktické postupy a činnosti při realizaci závazků Krajského Plánu odpadového hospodářství hlavního města Prahy byla mimo jiné monitorována efektivita sběru a čistota separovaného bioodpadu na sídlištích Prahy 15 a současně bylo analyzováno složení SKO z této lokality.

Monitoring na sídlišti probíhal v měsíčních intervalech. Byla sledována využitelnost kompostejnerů, čistota separovaného bioodpadu a složení SKO ze stejné oblasti bylo z kapacitních důvodů zjištováno jednou za dva měsíce. Nicméně byla pokryta všechna roční období.

Sít kompostejnerů je na sídlišti velmi hustá. Nacházejí se bud’v blízkosti kontejnerů pro SKO, nebo v blízkosti kontejnerových hnízd pro separovaný odpad. Donášková vzdálenost je menší než doporučovaných 100 metrů.

Rozbor SKO probíhal v areálu ZEVO Malešice Pražské služby, a. s., pomocí sít. Byly mimo jiné separovány dvě složky bioodpadu - zahradní odpad a "gastro" odpad, resp. ty složky, které nelze konzumovat, ale jsou vhodné pro kompostování.

Kontejnery nikdy nebyly plné a Ize říci, že četnost vyvážení je optimálně nastavená. Jako problematické se jeví ponechávání bioodpadů $\vee$ plastových sáčcích nebo zeleniny a ovoce $v$ původním plastovém obalu, $v$ kterém jsou prodávány. Často se v kompostejnerech nacházel SKO. Další komplikací je znečištění kontejnerư po vyprázdnění, kdy zejména v teplých ročních obdobích je doprovázeno znatelným výskytem hmyzu.

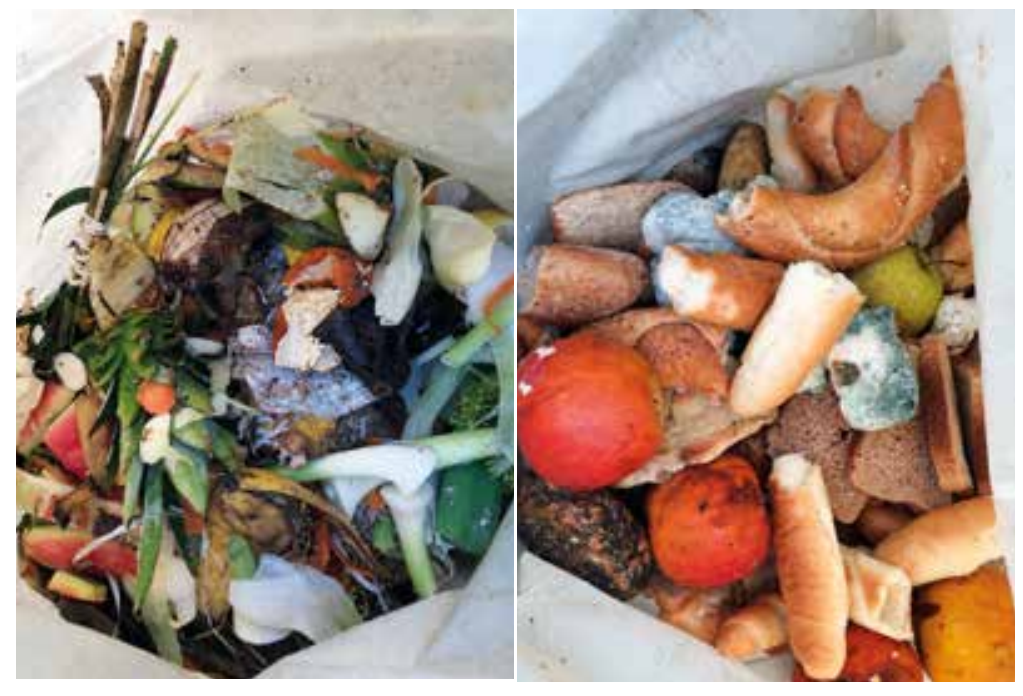

Obr. 3. Zahradní (vlevo) a gastro (vpravo) bioodpad

Fig. 3. Gardening (left) and food (right) biowaste

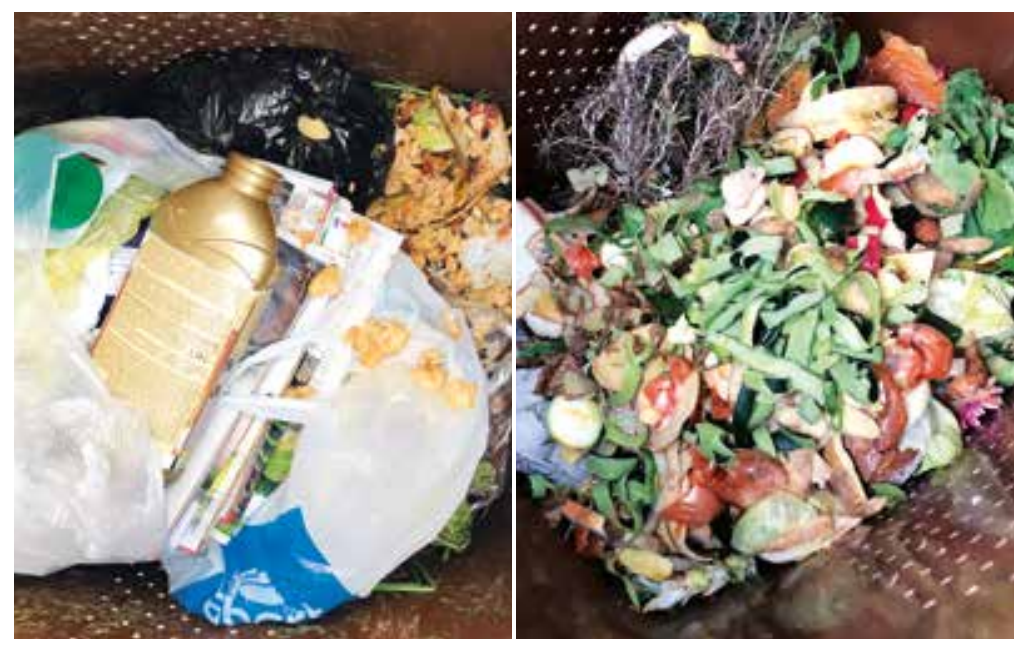

Obr. 4. Bioodpad s príměsí SKO (vlevo) a čistý bioodpad (vpravo)

Fig. 4. Biowaste with MSW (left) and clean biowaste (right)

Obsah bioodpadu v SKO byl oproti analyzovanému SKO z Prahy 1 a z Újezdu nad Lesy až o 5 \% nižší. V prípadě Újezdu nad Lesy zvýšené množství bioodpadu představuje zahradní odpad jako listí, posekaná tráva, pařezy, větve a to i přes to že i zde je propagováno domácí kompostování a možnost pronájmu kompostejneru. V Praze 1 je zvýšené množství "gastro" odpadu v bioodpadu způsobeno velkým množstvím restaurací, prodejen rychlého občerstvení a ubytovacích zařízení pro turisty. Z rozboru SKO ze sídlišt' Prahy 15 je vidět, že obyvatelé mají povědomí o důležitosti třídění bioodpadu, ale stále jsou zde rezervy jak sběr zlepšit. Je častým jevem, že bioodpad je vytříděn zvlášt v sáčku, nicméně zůstane v SKO. Domníváme se, že je to způsobeno specifičností tohoto druhu odpadu, který rychle podléhá rozkladu. Vznikající zápach a výskyt hmyzu spojený s neochotou minimálně denního vynášení zabraňuje lepšímu třídění. Možným řešením by mohly být nezaměnitelné biologicky rozložitelné sáčky jako v Pařizii, které by mohly být dostupné v supermarketech, domácích potřebách nebo obecním úřadě tak jako v Bruselu. 


\section{ZÁVĚR}

Zásadní otázkou pro udržitelnost měst je nakládání s odpady. V cirkulární ekonomice se obvykle jedná o tři etapy: snížení produkce, zlepšení sběru a opětovné získání materiálu a/nebo energie. Tyto tři etapy musí probíhat současně. Rozdílnost mezi jednotlivými městy/státy je způsobena dostupností finančních prostředkư, politickou a společenskou vưlí, technickými dovednostmi, vhodným plánováním, vymahatelnými právními predpisy a řadou dalších sociálních, demografických, kulturních a administrativních faktorů. Ochrana životního prostředí se stává stále důležitější globální prioritou a politické, obchodní a zdravotní výhody efektivního nakládání s odpady jsou jasné. Tyto skutečnosti by měly dát zemím stimuly, které potřebují k efektivnímu nakládání s jejich odpady.

Po prvním roce řešení projektu vyplývá, že kraj HI. m. Praha má zavedeno velmi dobré odpadové hospodářství. Spolu s Pražskými službami, a. s., se snaží o nastavení co nejefektivnější sítě sběrných nádob jak pro separované složky komunálního odpadu, tak i směsného komunálního odpadu, kterou Ize srovnávat s hlavními městy západní Evropy. Dostupnost a šíření informací o zpưsobech nakládání s odpady pro obyvatelstvo, osvětové akce v předškolních a školních zařízení jsou na velmi dobré úrovni. Jak Ize vidět u států, které jsou na špici v zavádění oběhového hospodářství, je to nekončící proces. Praha má v této oblasti stále rezervy, ale snaží se celý proces nakládání s bioodpady trvale zlepšovat. Jak efektivní zavedená opatření jsou, budeme moci říct na konci projektu v polovině roku 2020.

\section{Poděkování}

Príspěvek vznikl za podpory projektu CZ.07.1.02/0.0/0.0/16_040/0000379 Odpady a předcházení jejich vzniku - praktické postupy a činnosti při realizaci závazků Krajského Plánu odpadového hospodářství hlavního města Prahy.

\section{Literatura}

[1] BIDLINGMAIER, W., SIDAINE, J.M., and PAPADIMITRIOU, E.K. Separate collection and biological waste treatment in the European Community. Reviews in Environmental Science and Bio/Technology [online], 2004, vol. 3, No. 4, p. 307-320. ISSN 1569-1705, 1572-9826. Dostupné z: doi:10.1007/s11157-004-2334-1

[2] Database - Eurostat [online]. [citováno: 12. března 2019]. Dostupné z: https://ec.europa.eu/eurostat/ data/database

[3] Komunaliniu atlieku tvarkymo infrastruktūros plètra. Vilniaus Apskrities Atlieku Tvarkymo Centras [online]. [citováno: 14. března 2019]. Dostupné z: http://www.vaatc.lt/projektai/komunaliniu-atlieku-tvarkymo-infrastrukturos-pletra/

[4] Waste [online]. 28. November 2016 [citováno: 5. března 2019]. Dostupné z: https://www.brussels. be/waste

[5] Startseite [online]. [citováno: 13. března 2019]. Dostupné z: https://www.bsr.de/index.php

[6] AMSTERDAM. Waar laat ik mijn tuinafval? Amsterdam.nl [online]. [citováno: 7. března 2019]. Dostupné z: https://www.amsterdam.nl/veelgevraagd/

[7] Circular Organic Waste in Amsterdam [online]. [citováno: 13. března 2019]. Dostupné z: http:// organicwasteamsterdam.nl/

[8] PETERSEN, S.T. Biowaste Non-Sorters - Who Cares. 2018, p. 79.

[9] New Efforts to Sort Organic Waste in Copenhagen. State of Green [online]. 82017 [citováno: 13. března 2019]. Dostupné z: https://stateofgreen.com/en/partners/state-of-green/news/new-efforts-to-sort-organic-waste-in-copenhagen/

[10] Recycling in Luxembourg - Luxembourg. Angloinfo [online]. [citováno: 13. března 2019]. Dostupné z: http://www.angloinfo.com/how-to/luxembourg/housing/setting-up-home/recycling

[11] CITY OF VIENNA. Waste management in Vienna [online]. B.m.: City of Vienna. Dostupné z: https:// www.wien.gv.at/umwelt/ma48/service/publikationen/pdf/abfallwirtschaft-en.pdf

[12] PERCHARD, E. 'Urgent' need for London to curb incineration, says London Assembly. Resource Magazine [online]. 15. February 2018 [citováno: 13. března 2019]. Dostupné z: https://resource.co/ article/urgent-need-Iondon-curb-incineration-says-london-assembly-12405

[13] About waste management in London / London Councils. London Coucils [online]. [citováno: 13. března 2019]. Dostupné z: https://www.londoncouncils.gov.uk/our-key-themes/environment/ waste-and-recycling/about-waste-management-london
[14] Lisbon City Council: Partners: Regions for Recycling [online]. [citováno: 13. března 2019]. Dostupné z: http://www.regions4recycling.eu/partners/Lisbon_City_Council

[15] Sítio da Câmara Municipal de Lisboa: WasteSeparation Rules [online]. [citováno: 13. března 2019]. Dostupné z: http://www.cm-lisboa.pt/en/living-in/urban-cleaning/waste-disposal/waste-separation-rules

[16] guidaFAMIGLIE_BUTTAbene_OLGIATA-ing_WEB.pdf [online]. [citováno: 3. března 2019]. Dostupné z: http://www.amaroma.it/public/files/pap/guidaFAMIGLIE_BUTTAbene_OLGIATA-ing_WEB.pdf

[17] BELL, B. Why Rome sends trains filled with rubbish to Austria. BBC News [online]. 2017 [citováno: 13. března 2019]. Dostupné z: https://www.bbc.com/news/world-europe-39641761

[18] Treatment of biowaste |HSY. Helsinki Region Environmental Services Authority - HSY [online]. 24. May 2018 [citováno: 4. března 2019]. Dostupné z: https://www.hsy.fi:443/en/experts/waste-management/ ammassuo-waste-treatment-centre/Pages/Treatment-of-biowaste.aspx

[19] Waste management regulations | HSY. HSY-Helsinki Region Environmental Services Authority [online]. 11. August 2018 [citováno: 4. března 2019]. Dostupné z: https://www.hsy.fi:443/en/residents/sorting/ waste-management-regulations/Pages/default.aspx

[20] KOUVO, P., A. KAINULAINEN, and K. KOIVUNEN. Separate Collection System of Recyclables and Biowaste Treatment and Utilization in Metropolitan Area Finland. International Journal of Environmental and Ecological Engineering. no date, vol. 2017, No. 6, p. 6. ISSN ISNI:0000000091950263.

[21] DE CLERCQ, G. Paris restaurants turn food scraps into biogas. Reuters [online]. 2014 [citováno: 4. března 2019]. Dostupné z: https://www.reuters.com/article/us-biogas-france-restaurants-idUSBREA1B1A020140212

[22] Tri-collecte-traitement-des-biodechets.pdf [online]. [citováno: 13. března 2019]. Dostupné z: https:// www.syctom-paris.fr/fileadmin/mediatheque/documentation/doc/Tri-collecte-traitement-desbiodechets.pdf

[23] CONTRIBUTOR. Paris Parks \& Gardens: Composting in Paris. France Revisited - Life in Paris, Travel in France [online]. 7. November 2017 [citováno: 4. března 2019]. Dostupné z: http://francerevisited. com/2017/11/paris-parks-gardens-composting/

[24] Paris rolls out separate food waste collection. Resource Magazine [online]. 52017 [citováno: 4. března 2019]. Dostupné z: https://resource.co/article/paris-rolls-out-separate-food-waste-collection-11873

[25] rapport_sur_le_prix_et_la_qualite_du_service_public_de_gestion_des_dechets_2017.pdf [online]. [citováno: 4. března 2019]. Dostupné z: http://filer.paris.fr/parisfr/rapport_sur_le_prix_et_la_qualite_ du_service_public_de_gestion_des_dechets_2017.pdf

[26] DAHLÉN, L., VUKICEVIC, S., MEIJER, J.E., et al. Comparison of different collection systems for sorted household waste in Sweden. Waste Management [online], 2007, vol. 27, No. 10, p. 1298-1305. ISSN 0956053X. Dostupné z: doi:10.1016/j.wasman.2006.06.016

[27] The Swedish recycling revolution. sweden.se [online]. 15. November 2013 [citováno: 6. března 2019]. Dostupné z: https://sweden.se/nature/the-swedish-recycling-revolution/

[28] Wastecosmart - STOCKHOLM REGION CLUSTER, SE [online]. [citováno: 6. března 2019]. Dostupné z: http://www.wastecosmart.eu/en/cluster-regions/sweden

[29] Sofia :: Partners :: Regions for Recycling [online]. [citováno: 5. března 2019]. Dostupné z: http://www. regions4recycling.eu/partners/Sofia

[30] Municipal waste management in Croatia - race against time. Balkan Green Energy News [online]. 7. February 2018 [citováno: 5. března 2019]. Dostupné z: https://balkangreenenergynews.com/ municipal-waste-management-croatia-race-time/

[31] Néa. Athens biowaste [online]. [citováno: 11. března 2019]. Dostupné z: http://www.biowaste.gr/ site/links/

[32] WasteServ Malta - Organic [online]. [citováno: 7. března 2019]. Dostupné z: https://www. wasteservmalta.com/organic

[33] MARKOVIĆ, D., SCHNEIDER, D.R., and STEFANOVIĆ, G. Life cycle assessment of solid waste management: Case study of Zagreb, Croatia. In: 2nd Conference of Sustainable Development and Climate Changes / 2. konferencija Održivi razvoj i klimatske promene: Proceedings of the 2nd Conference of Sustainable Development and Climate Changes [online]. Niš, Srbija: Faculty of Mechanical Engineering, University in Nis, 2010, p. 110-117 [citováno: 5. března 2019]. ISBN 978-86-6055-004-2. Dostupné z: http:// bib.irb.hr/prikazi-rad?rad=499600

[34] www.urbanbiogas.eu - City of Zagreb [online]. [citováno: 5. března 2019]. Dostupné z: https://www. urbanbiogas.eu/city-of-zagreb

[35] City of Warsaw Introduction of bio-waste collection [online]. 8. September 2018 [citováno: 4. března 2019]. Dostupnéz:http://www.acrplus.org/fr/actualites/actualites-de-nos-membres/1729-warsaw-introduction -of-bio-waste-collection

[36] New rules of waste management in Poland. JustAsk Poland [online]. 8. July 2017 [citováno: 4. března 2019]. Dostupné z: https://www.justaskpoland.com/new-rules-of-waste-management-in-poland/

[37] pl_Report_Waste-management-in-Poland.pdf [online]. [citováno: 4. března 2019]. Dostupné z: http:// nlchamber.com.pl/wp-content/uploads/2014/01/pl_Report_Waste-management-in-Poland.pdf

[38] Vilniaus Apskrities Atlieku Tvarkymo Centras. VAATC [online]. Dostupné z: http://www.vaatc.lt/ projektai/komunaliniu-atlieku-tvarkymo-infrastrukturos-pletra/\&prev=search

[39] Bratislava | Triedený odpad. Bratislava [online]. [citováno: 4. března 2019]. Dostupné z: https:// bratislava.sk/sk/triedeny-odpad 
[40] Souhrnné informace o produkci a nakládání s odpady v hl.m. Praze (Portál životního prostřed hlavního města Prahy) [online]. [citováno: 14. března 2019]. Dostupné z: http://portalzp.praha.eu/jnp cz/odpady/souhrnne_informace/index.xhtml

[41] Sezonní svoz bioodpadu - Pražské služby, a. s. [online]. [citováno: 5. April 2019]. Dostupné z: https:// www.psas.cz/index.cfm/sluzby-firmam/odpady/svoz-bioodpadu/uzavreni-smlouvy-online/ navrh-sezonni-smlouvy/

[42] TV PRAHA, T.P. Svoz bioodpadu využívají Pražané stále častěji | PRAHA | Zprávy | PRAHA TV. Praha TV [online]. 112018 [citováno: 15. března 2019]. Dostupné z: http://prahatv.eu/zpravy/praha/ praha/8872/svoz-bioodpadu-vyuzivaji-prazane-stale-casteji

\section{Autoři}

Ing. Dagmar Vološinová

凶dagmar.volosinova@vuv.cz

Ing. Robert Kořínek, Ph.D.

凶robert.korinek@vuv.cz

Ing. Elžbieta Čejka

凶elzbieta.cejka@vuv.cz

Výzkumný ústav vodohospodářský T. G. Masaryka, v. v. i.

Příspěvek prošel lektorským řízením.

\section{WAYS OF BIOWASTE MANAGEMENT IN PRAGUE AND IN SELECTED MAJOR CITIES OF THE EUROPEAN UNION}

\section{VOLOSINOVA, D.; KORINEK, R.; CEJKA, E.}

TGM Water Research Institute, p.r.i.

Keywords: biowaste - waste management - circular economy composting - anaerobic digescion - European Union

Biowaste or waste subject to the anaerobic or aerobic decomposition has become a problematic component of the municipal waste due to the use of green spaces, especially in the large cities with a high population density. Biowaste can be seen as a source of the hazardous methane released by landfilling, but thanks to the principles of the circular economy we return to its essence - a source of nutrients and organic matter for agricultural land and urban greenery. The success of biowaste collection, treatment and return to the environment varies between the major capitals of the Member States of the European Union. The article describes how effectively Prague deals with the issue compared to other selected major capitals European Union. 